\title{
Three DPP-IV inhibitory peptides from Antarctic krill protein hydrolysate improve glucose levels in the zebrafish model of diabetes
}

\author{
Wei JI ${ }^{1 \star}$ (D), Chaohua ZHANG ${ }^{2,3}$, Cai SONG ${ }^{3}$, Hongwu JI ${ }^{2,3}$
}

\begin{abstract}
Ala-Pro (AP), Ile-Pro-Ala (IPA) and Ile-Pro-Ala-Val-Phe (IPAVF) as DPP-IV inhibitory peptides were purified from Antarctic krill protein hydrolysate (AKH). Diabetic zebrafish model was rapidly induced with combination of high glucose immersing and cholesterol diet for evaluation the three DPP-IV inhibitory peptides activity. Physiochemical indexes including DPP-IV activity, glucose, triglyceride and cholesterol; the relative gene (insa, glucagon and pck1) expressions levels were detected. The results showed that after 15 days of peptides treatment, the physiochemical index levels of peptide groups were significantly higher than that of negative control and showed dose-dependent effect. The insa gene expression level would be increased with the enhancement of peptide concentration, whereas gene expression levels of glucagon and pck1 would be decreased. These results indicated that three peptides all had hypoglycemic effects in different degree. It suggested the potential of AKH containing DPP-IV inhibitory peptides could be as functional food supplement to treat diabetes.
\end{abstract}

Keywords: DPP-IV inhibitory peptides; diabetic zebrafish; glycemic level; Antarctic krill hydrolysate.

Practical Application: Antarctic krill protein hydrolysate containing DPP-IV inhibitory peptides used as functional food supplement to treat diabetes.

\section{Introduction}

Type 2 diabetes is a chronic metabolic disorder characterized by high blood glucose due to insufficient insulin secretion and insulin resistance. This disorder is widespread, severely debilitating, and affects a large portion of the global population (Thomas et al., 2019). Treatments of Type 2 diabetes include diet, exercise, and anti-diabetic medication (Jannoo et al., 2017). Currently, its pathobiology is complex and poorly understood, necessitating novel approaches to its therapy. Recent focus on nutrition has shifted towards searching for novel therapies and diets to treat and prevent metabolic disorders, including diabetes. Antarctic krill (Euphausia superba) has 3-10 billion fishing tons annual globally. It contains $11.9-15.4 \%$ proteins (Ji et al., 2017) that include all essential amino acids, and is particularly enriched in proline, methionine, leucine and lysine (Wang et al., 2015; Sun \& Mao, 2016). It's also a good resource for extracting bio-active peptides, such as DPP-IV inhibitor for diabetes, for nutritional or medical purposes.

DPP-IV inhibitors are considered as an efficient pharmacotherapy for managing type 2 diabetes (Lacroix \& Li-Chan, 2016) by protecting the activity of Glucagon like peptide-1 (GLP-1) and glucose-dependent insulinotropic polypeptide (GIP) from being cleaved by DPP-IV (Zhang et al., 2015). This, in turn, increases insulin secretion by islet $\beta$-cells, and decreases glucagon secretion, thereby decreasing blood glucose concentration (Yabe et al., 2015). A recent study (Lacroix \& Li-Chan, 2012) listed 34 dietary proteins serving as precursors of DPP-IV inhibitors, containing 2-13 amino acids. Importantly, most of DPP-IV inhibitory peptides contain proline and/or hydrophobic amino acids within their sequence and varying effects (Minkiewicz et al., 2011; Hatanaka et al., 2012). Therefore, Antarctic krill may be a likely potential resource of DPP-IV inhibitory peptides.

To date, evaluation of DPP-IV inhibitory peptides in vivo has been performed using animal experimental models, including mice (Liu et al., 2009), rats, (Gonçalves et al., 2014) dogs, monkeys (Lee et al., 2008) and rabbits (Yamamoto et al., 2015). Although mammals have a better similarity to humans, they also show some experimental disadvantages, such as low throughput (BritoCasillas et al., 2016). Considering these limitations, fish as model organisms are widely used for modeling human disease and drug screening (Maher, 2009; Liang et al., 2013). Zebrafish (Danio rerio) is a low-cost model animal with a rapid lifecycle, small size and optical transparency (Stewart et al., 2014). Due to its high genic similarity with humans (80-85\%) and time/space-effective nature, the zebrafish represents a unique and powerful animal model 
in biomedicine (Lawson \& Weinstein, 2002). In addition, being similar to mammals, zebrafish has pancreas with two types of glandular tissues, which carry out essential physiological functions (Tiso et al., 2009). Like humans, the regulation of zebrafish glucose metabolism occurs through the secretion of insulin and glucagon directly in the bloodstream (Wang et al., 2013). Zebrafish genes coding insulin and glucagon, as well as other regulators of glucose metabolism, are also similar to those encoding mammalian metabolic proteins (Gleeson et al., 2007). To establish a diabetic zebrafish model, a combined high-cholesterol diet and highglucose immersion method has been previously successfully used (Wang et al., 2013). The aim of the present study is to set up a diabetic zebrafish model and investigate putative glycemic effects of three novel DPP-IV-inhibiting peptides isolated from Antarctic krill protein hydrolysates.

\section{Materials and methods}

\subsection{Materials and reagents}

Antarctic krill biomass was obtained from China National Fisheries Corporation (Beijing, China) with moisture $76.82 \%$, protein $16.80 \%$, fat $2.05 \%$, sugar $0.81 \%$ and ash $3.52 \%$. The DPP-IV inhibitor screening assay kit was purchased from Sigma Chemicals Co. Ltd. (St. Louis, MO, USA). Animal proteolytic enzyme was obtained from Pangbo Biological Engineering Co. Ltd. (Nanning, Guangxi, China). The DPP-IV assay kit was purchased from Enzo Life Sciences, Inc. (Famingdale, NY, USA). ELISA kits of triglyceride, protein, and cholesterol were obtained from Jiancheng Biological Engineering Research Institute (Nanjing, Jiangsu, China). Animal tissue glucose reagent kit was obtained from Keming Biological Engineering Co. Ltd. (Suzhou, Jiangsu, China). Zebrafish flake was bought from Shanghai Polishing Aquarium Supplies Co., Ltd. (Shanghai, China) and contained $40 \%$ protein, $7 \%$ fat, and $9 \%$ fiber. Cholesterol was purchased from Aladding (Shanghai, China) and Invitrogen TRIzol from Thermo Fisher Scientific Inc., (Shanghai, China). The assay kits of Prime ScriptTM RT Master Mix (Code No.RR820A) and SYBER ${ }^{\circledR}$ Premix Ex TaqTM II (Code No.RR036A) were the products of TaKaRa (Takara Bio Inc., Beijing, China). The RT-PCR related consumables were sterile and had no RNA enzymes (Corning, Silicon Valley, CA, USA).

\subsection{Determination of DPP-IV inhibitory activity in vitro}

The DPP-IV inhibitory activity was measured according to Matheeussen et al. (2012) with modifications. Briefly, each sample was dissolved in the buffer, and $30 \mu \mathrm{L}$ of sample solution, $10 \mu \mathrm{L}$ of DPP-IV, inhibitor or $10 \mu \mathrm{L}$ of solvent were added in the plate wells. The reaction was initiated by adding $50 \mu \mathrm{L}$ of diluted substrate solution to all wells. Plates were incubated for $30 \mathrm{~min}$ at $37^{\circ} \mathrm{C}$ with microplate reader (Varioskan Flash, Thermo Fisher Scientific Co., NY, USA). The fluorescence was measured microplate reader at the excitation $355 \mathrm{~nm}$ wavelength and emission $460 \mathrm{~nm}$ wavelength. All the steps were performed in dark environment. The inhibition activity was calculated using the following equation: DPP-IV inhibition activity $=[(\mathrm{A}-$ $\mathrm{B}) / \mathrm{B}] \times 100 \%$, where $\mathrm{A}$ is the negative group (solution without adding DPP-IV inhibitors), $\mathrm{B}$ is the sample or positive group (solution containing sample or DPP-IV inhibitor). The halfmaximal inhibitory concentration $\left(\mathrm{IC}_{50}\right)$ values were calculated by plotting the logarithm of the concentration of the sample $(\mathrm{mg} / \mathrm{mL})$ against the inhibitory activity (\%).

\subsection{Preparation of DPP-IV inhibitory peptides}

Antarctic krill and distilled water were mixed for hydrolyze, with animal proteolytic enzyme $(230 \mathrm{U} / \mathrm{g})$ at $45{ }^{\circ} \mathrm{C}$ for $3.8 \mathrm{~h}$. The suspension was centrifuged and collected for ultrafiltration. 4 fractions of different molecular were collected as follows: $\mathrm{MW}>5000 \mathrm{kDa}(\mathrm{AKH}-1), \mathrm{MW}=5000-3000 \mathrm{Da}(\mathrm{AKH}-2)$, $\mathrm{MW}=3000-100 \mathrm{Da}(\mathrm{AKH}-3)$ and $\mathrm{MW}<100 \mathrm{Da}$ (AKH-4). With the highest DPP-IV inhibitory activity fraction was purified using Sephacryl S-100 column $(1.6 \mathrm{~cm} \times 58 \mathrm{~cm}, 116 \mathrm{~mL}$, General Electric Company, Fairfield, Connecticut, USA) by protein purification system (AKTA purifier 100, General Electric Company) for further purification. Fractions with the highest levels of DPP-IV inhibitory activity was further purified by 1200 semi-preparation RP-HPLC (Agilent Technologies Inc., Guangzhou, China) on a C18 column ( $5 \mu \mathrm{m}, 4.6 \times 250 \mathrm{~mm}$, Waters, Milford, MA, USA). The purified peptides were analyzed by QTOF mass spectrometer. Peptides identified were prepared by 1200 semi-preparation RPHPLC on a YMC-Pack Pro C18 column $(5 \mu \mathrm{m}, 10.0 \times 250 \mathrm{~mm}$, Waters, Milford, MA, USA), eluted by methanol and water (5:95) at $214 \mathrm{~nm}$ absorbance for evaluation of the hypoglycemic effect of diabetic zebrafish (Ji et al., 2017).

\subsection{Establishment of diabetic zebrafish model}

A total of 350 adult short-fin outbred wild type zebrafish of both sexes were acclimated for at least 5 days prior to testing. The zebrafish were housed in groups of 40 in a $30 \mathrm{~L}$ plastic tanks at $\left.26 \pm 2{ }^{\circ} \mathrm{C}\right)$ under constant water filtration and aeration $(7.20 \mathrm{mg}$ $\left.\mathrm{O}_{2} / \mathrm{L}\right)$. Fish were maintained under the $14 \mathrm{~h} / 10 \mathrm{~h}$ day/night photoperiod cycle and fed twice a day with commercial flakes. According to Capiotti et al. (2014) with modifications, experimental zebrafish were immersed in $20 \mathrm{~g} / \mathrm{L}$ glucose solution and fed with $0.003 \mathrm{~g}$ flakes containing $10 \%$ cholesterol, twice a day, for 20 days. The cholesterol diet was commercial flakes containing $10 \%(\mathrm{~W} / \mathrm{W})$ cholesterol after ether evaporation, and $0.003 \mathrm{~g}$ was fed to each zebrafish twice a day.

\subsection{Treatment with DPP-IV inhibitory peptides}

Thirty zebrafish of each experimental group were immersed in three different concentrations of each peptide solution (39.06, 78.12 and $156.25 \mathrm{mg} / \mathrm{L}$ ) with filtration for $5 \mathrm{~min}$ at 9.00 a.m daily, for 15 days. The high concentration value was determined experimentally and selected as the highest level that gave no abnormal side-effects, such as eye redness and swelling after immersing in peptide solution for $15 \mathrm{~min}$. The selection of the middle and low concentrations was based on the selected high concentration.

\subsection{Assay for physicochemical indices}

Wild type larvae zebrafish $(\mathrm{AB})$ of each experimental group were euthanized by ice and washed twice in double distilled water. The body parts were pooled and homogenized with a 
high-speed homogenizer. The protein concentrations in the homogenates were determined using BCA (bicinchoninic acid) assay kits. The levels of glucose, cholesterol and triglycerides in the homogenates were detected by the spectrophotometer methods, according to the reagent kit instructions, and the results were standardized by total protein levels.

\subsection{Gene expression analysis by quantitative real time PCR}

Ten euthanized zebrafish were homogenized with the Trizol. The total RNA was isolated from the homogenized tissues according to the manufacturer's instructions. Thereafter, the isolated RNA was reversely transcribed by Prime ScriptTM RT Master Mix and cDNA was stored $4 \mathrm{oC}$. For fluorescent detection of PCR products, reactions containing template and specific primers (Table 1) were amplified with SYBER ${ }^{\circledR}$ Premix Ex TaqTM II. The PCR cycling conditions were as follows: an initial denaturation step for $5 \mathrm{~min}$ at $95^{\circ} \mathrm{C}, 39$ cycles of $10 \mathrm{~s}$ at $95^{\circ} \mathrm{C}$ for denaturation and $30 \mathrm{~s}$ at $60^{\circ} \mathrm{C}$ for annealing and extension, followed by $10 \mathrm{~s}$ at $95^{\circ} \mathrm{C}$ for dissociation. At the end of the cycling protocol, a melting-curve analysis was included and fluorescence was measured from $65^{\circ} \mathrm{C}$ to $95^{\circ} \mathrm{C}$. Relative expression levels were calculated by the CT method (Schmittgen \& Livak, 2008).

\subsection{Statistical analysis}

Data were expressed as means \pm standard deviations from triplicate measurements for each sample $(n=3)$. The statistical analysis was performed SPSS 10.0 software (SPSS Inc., Chicago, IL, USA) using by the Tukey test for multiple comparison. The significant difference was established at $\mathrm{P}<0.05$.

\section{Results and Discussion}

\subsection{Establishing the diabetic zebrafish model}

Compared with traditional experiment animals, the amount of tested sample in zebrafish experiment was needed less, largely reducing the cost. Besides, adult zebrafish easily absorb molecules from water, due to an ability to regulate their internal water and total solute concentrations (Sun et al., 2019). In zebrafish, the glucose absorption/uptake occurs through a glucose transporter, called GLUT, expressed in the gills (GLUT 1-3, 6, 8, and 10-13) and intestine (GLUT 5 and 9) (Papasani et al., 2004). Excess glucose in aquatic environment in zebrafish induces symptoms related to the pathophysiology of diabetes, supporting the utility of glucose/cholesterol exposure to induce hyperglycemic diabetic-like states (Gleeson et al., 2007). To valid the evoked effects further, physiochemical parameters were also assessed here, including DPP-IV activity, triglyceride, cholesterol levels and the expression of insulin-related genes insa, glucagon and pck1. Since DPP-IV inhibitors block the DPP-IV enzymes and prevent them from maintaining normal blood glucose levels, monitoring the DPP-IV activity reflects the extending of DPPIV inhibition (Juillerat-Jeanneret, 2014). Other physiochemical parameters, such as glucose, triglyceride and cholesterol, may fluctuate with glycemic change (Wang et al., 2013). Insulin and glucagon hormones modulate the blood glucose in humans (James et al., 2017). In zebrafish, there are two subtypes of insulin genes, insa and insb (Tulipano et al., 2011) The insa functions generally resemble those of its mammalian homologue, playing a role in glucose regulation, whereas insb is believed to play a more important role in zebrafish development. Glucagon elevates the cAMP levels by activating adenylate cyclase, which indirectly increases the expression of phosphoenolpyruvate carboxykinase (PEPCK) (Montal et al., 2015). PEPCK has two forms, pck1 in the cytoplasm, and pck2 in the mitochondria (JuilleratJeanneret 2014). Since PEPCK catalyzes the rate-controlling step of gluconeogenesis, the process by which cells synthesize glucose from metabolic precursors, the blood glucose level is maintained within well-defined physiological limits partly as a result of the precise regulation of PEPCK gene expression (Elo et al., 2007). Previous studies demonstrated PEPCK as a good indicator of blood glucose levels (Chiu et al., 2018). Adult zebrafish respond to anti-diabetic drugs (cAMP-DEX, metformin, and rosiglitazone) similarly to mammalian models, by reducing blood glucose levels and showing increased insulin and decreased glucagon and PEPCK levels. The zebrafish pck1 exhibits similar regulation patterns and activity to its mammalian counterpart (Elo et al., 2007). Glycemic levels in diabetic zebrafish could be controlled efficiently through the evaluation of these parameters. Previous research has shown that chronic 2-week $111-\mathrm{mm}$ glucose exposure induces overt hyperglycemia in zebrafish model (Capiotti et al., 2014). Revealing the stability of the model after withdrawal from glucose, the diabetic-like state was maintained for 20 days, i.e., 6 days longer than the hyperglycemia zebrafish model (Capiotti et al., 2014).

In the diabetes zebrafish model here, physicochemical indices related to glycemic levels, such as glucose, triglyceride and cholesterol, were predictably increased after this treatment (Figure 1). This was generally consistent with earlier reports (Wang et al., 2013) that blood glucose, triglyceride, and cholesterol parameters increased several folds in the treatment group, confirming the validity of the evoked diabetic model in zebrafish used here. Interestingly, this result was similar with that observed in the experimental diabetic rat model (Huang et al., 2014).

Table 1. Primers for RT-qPCR.

\begin{tabular}{lcc}
\hline \multicolumn{1}{c}{ Gene } & Forward Primer & Reverse Primer \\
\hline$\beta$-actin & CATCAGGGTGTCATGGTTGGT & TCTCTTGCTCTGAGCCTCATCA \\
Insa & GAGCCCCTTCTGGGTTTCC & AAGTCAGCCACCTCAGTTTCCT \\
Glucagon & AAGCGAGGAGACGATCCAAA & TCCAACACACACCAGCAAATG \\
$P$ ck 1 & AGAGCCATCAACCCAGAGAA & CCACGTTGGTGAAGAGTGTG \\
\hline
\end{tabular}

Note: $\beta$-actin, insa and glucagon genes were cited from Wang et al. (2013). pck1 gene was designed by Sangon Biotech (Shanghai) Co., Ltd. (China). 
In order to evaluate the effects on glycemic hormones, the gene expression of insa, glucagon and pck1 was examined. Compared to the control treatment-free group, the expression of insa gene was reduced by half, whereas the relative expression of glucagon and pck1 genes was 5-6 times lower vs. controls (Figure 2). A recent study (Matheeussen et al., 2012) used $111 \mathrm{~mm}$ glucose solution expose for 2 weeks to induce zebrafish diabetes in-vivo, showing that the eye glycosylated protein rose, and insulin mRNA level declined vs. the treatment-free controls. Following the removal from glucose solution, zebrafish glucose levels were also higher than the control group, further confirming the use of glucose immersion with high-cholesterol diet here as a method for zebrafish diabetes modeling.

\subsection{Physicochemical indexes of three peptides lowering blood glucose}

Three DPP-IV inhibitory peptides, AP, IPA and IPAVF were identified and prepared. In order to evaluate hypoglycemic effects of them, diabetic zebrafish were immersed daily in three different concentrations $(39.06,78.12$ and $156.25 \mathrm{mg} / \mathrm{L}$ ) of each



Figure 1. Physicochemical indices of diabetic zebrafish model (Control group: zebrafish immersed in water with normal diet for 20 days. Experimental group: zebrafish immersed in 20 g/L glucose solution and fed with flakes containing $10 \%$ cholesterol diet for 20 days.)



Figure 2. Relative gene expression in zebrafish diabetes model. peptide for $5 \mathrm{~min}$ for 15 days. Physicochemical indices assessed here included the DPP-IV activity, total glucose, triglyceride, and cholesterol in the whole body, measured using the respective reagent kits.

As shown in Figure 3, compared to negative control group, the activity of three DPP-IV inhibitory peptides in the experimental group were decreased, depending on the peptide type and concentration. All medium and high concentration groups significantly differed from the negative control group (Figure 3). Compared to the positive group, the high concentration group of IPA had no significant differences, indicating that IPA has a better inhibitory effect in this model. The glucose level measured reflects the glycemic level directly, whereas the levels of triglyceride and cholesterol reveal hypoglycemic function from side reactions. Figure 4 showed that relative to the negative control, the three physiochemical indices for all peptide groups were decreased in a dose-dependent manner, with IPA being the most potent inhibitor.

\subsection{Gene expressions levels of three peptides lowering blood glucose}

insa gene expression level reflects the insulin level in animals. As shown in Figure 5, insa gene expression levels in diabetic zebrafish from all three peptides groups were higher than in negative control. For each peptide, the insa gene expression levels in diabetic zebrafish positively correlated with peptide concentration. The three DPP-IV inhibitory peptides tested here promoted the insa gene expression in diabetic zebrafish and accelerated the secretion of insulin, which suggests that they may improve glycemic levels. Glucagon and insulin are mutually antagonistic hormones. The similarity between the mammalian and zebrafish PEPCK promoters (Wang et al., 2013) suggests that the zebrafish PEPCK promoter contains the regulatory elements necessary for proper tissue-specific expression, as well as the expression in response to glucagon, glucocorticoids, and insulin (Elo et al., 2007). As shown in Figure 5, compared to negative control, glucagon and pckl gene expression for all peptide groups was decreased to different degrees, but remained higher than in the positive control group. Decreasing glucagon and pck1 expression levels depended on peptide concentrations used: the higher the peptide concentration corresponds to the lower gene expression. Of the three peptides tested, IPA showed the stronger inhibition of glucagon and $p c k 1$ gene expression, and the group treated with the highest concentration of IPA showed the lowest glucagon and pck1 expression. In conclusion, IPA showed overt hypoglycemic effect, which coincided with the lowest $\mathrm{IC}_{50}$ value of DPP-IV inhibitory activity.

\section{Conclusions}

The combination of high-cholesterol diet and glucose exposure rapidly induced the onset of diabetic-like states in zebrafish, emerging as valuable and useful model for screening anti-diabetic components, including DPP-IV inhibitors. The three DPP-IV inhibitory peptides, AP, IPA and IPAVF, purified from Antarctic krill protein hydrolysate, exhibited robust hypoglycemic effect, thus demonstrating the potential for Antarctic krill 

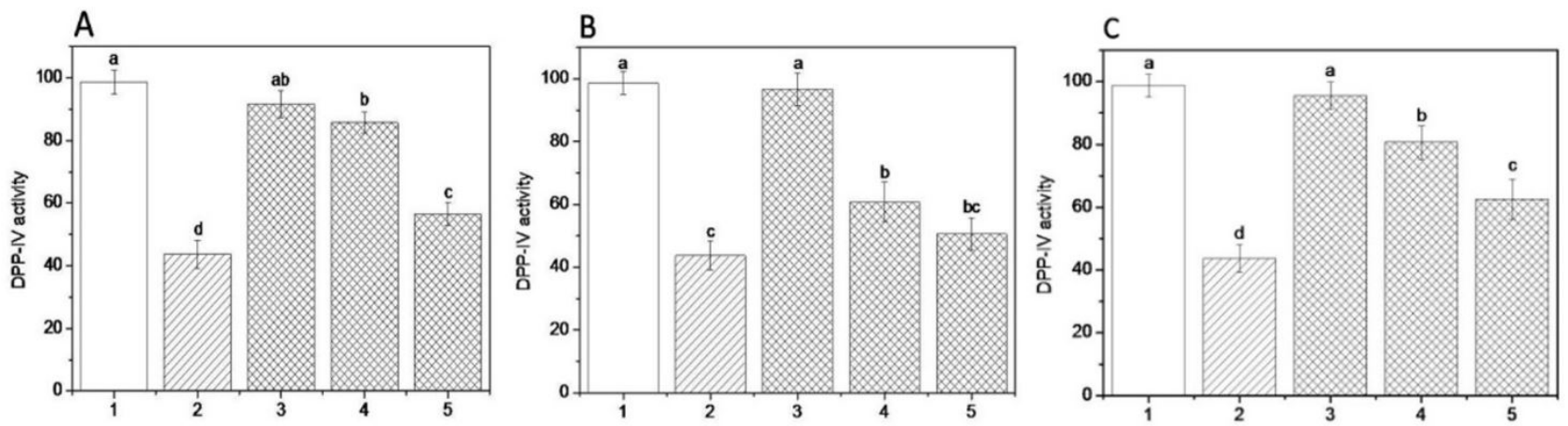

Figure 3. DPP-IV activity determination of diabetic zebrafish treated with DPP-IV inhibitory peptides after 15 days (A:AP; B:IPA; C:IPAVF; 1:negative control; 2:positive control:130.7 mg/L Sitagliptin; 3:39.06 mg/L; 4:78.12 mg/L; 5:156.25 mg/L) The same corner mark of alphabets represented the same comparable group. Letters denote significant differences, $\mathrm{P}<0.05$.
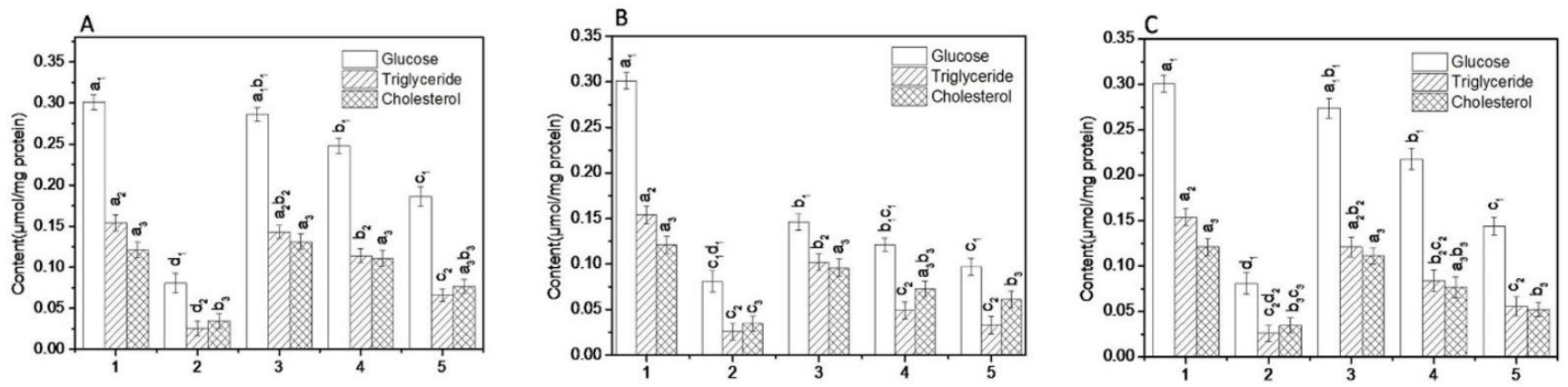

Figure 4. Physicochemical indices levels of diabetic zebrafish immersed in three peptides solution, $5 \mathrm{~min} /$ day, for 15 days. (1: negative control without disposing; 2: 130.7 mg/L Sitagliptin solution; 3: $39.06 \mathrm{mg} / \mathrm{L}$ AP (A); $39.06 \mathrm{mg} / \mathrm{L}$ IPA (B); $39.06 \mathrm{mg} / \mathrm{L}$ IPAVF (C); 4: 78.12 mg/L AP (A); 78.12 mg/L IPA (B); 4: $78.12 \mathrm{mg} / \mathrm{L}$ IPAVF (C); 5: $156.25 \mathrm{mg} / \mathrm{L}$ AP (A); $156.25 \mathrm{mg} / \mathrm{L}$ IPA (B); $156.25 \mathrm{mg} / \mathrm{L}$ IPAVF (C). Letters denote significant differences, P<0.05.)
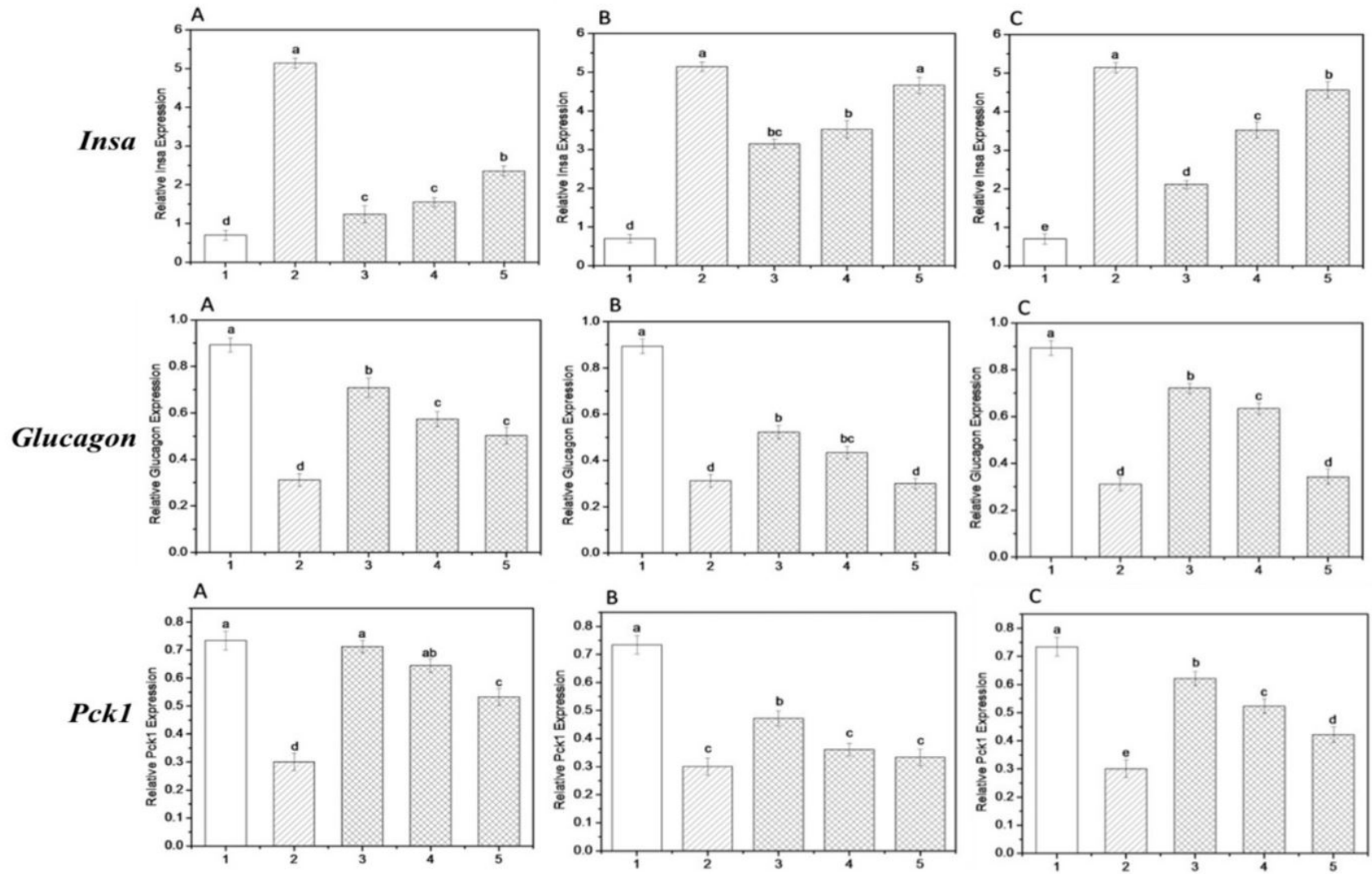

Figure 5. Relative insa, glucagon and pck1 expression of diabetic zebrafish immersed in three peptides solution, 5 min/day, for 15 days. (1: negative control without disposing; 2: $130.7 \mathrm{mg} / \mathrm{L}$ Sitagliptin solution; 3:39.06 mg/L AP (A); $39.06 \mathrm{mg} / \mathrm{L}$ IPA (B); 39.06 mg/L IPAVF (C); 4: $78.12 \mathrm{mg} / \mathrm{L} \mathrm{AP} \mathrm{(A);} 78.12 \mathrm{mg} / \mathrm{L}$ IPA (B); 4: 78.12 mg/L IPAVF (C); 5: 156.25 mg/L AP (A); 156.25 mg/L IPA (B); 156.25 mg/L IPAVF (C). Letters denote significant differences, P<0.05.) 
protein hydrolysate (containing DPP-IV inhibitory peptides) as a functional food or food supplement for management of type 2 diabetes.

\section{Acknowledgements}

We greatly appreciate the assistance provided by the staff of the Research Institute for Marine Drugs and Nutrition of Guangdong Ocean University. We also thank all volunteers for their participation in the study. This work was co-supported by the Modern Agroindustry Technology Research System of China (CARS-48), National Natural Science Foundation of China (No. 31801614), Fund of Guangdong Provincial Key Laboratory of Aquatic Products Processing and Safety (GDPKLAPPS1703) of China.

\section{References}

Brito-Casillas, Y., Melián, C., \& Wägner, A. M. (2016). Study of the pathogenesis and treatment of diabetes mellitus through animal models. Endocrinología y Nutrición, 63(7), 345-353. http://dx.doi. org/10.1016/j.endonu.2016.03.011. PMid:27246633.

Brown, E. C., Franklin, B. A., Regensteiner, J. G., \& Stewart, K. J (2020). Effects of single bout resistance exercise on glucose levels, insulin action, and cardiovascular risk in type 2 diabetes: A narrative review. Journal of Diabetes and Its Complications, 34(8), 107610. http://dx.doi.org/10.1016/j.jdiacomp.2020.107610. PMid:32402840.

Capiotti, K. M., Junior, R. A., Kist, L. W., Bogo, M. R., Bonan, C. D., \& Silva, R. S. D. (2014). Persistent impaired glucose metabolism in a zebrafish hyperglycemia model. Comparative Biochemistry and Physiology. Part B, Biochemistry \& Molecular Biology, 171, 58-65. http://dx.doi.org/10.1016/j.cbpb.2014.03.005. PMid:24704522.

Chiu, C. Y., Hsu, W. H., Liu, H. K., Liu, S. H., \& Lin, Y. L. (2018). Prepared Rehmanniae Radix oligosaccharide regulates postprandial and diabetic blood glucose in mice. Journal of Functional Foods, 41, 210-215. http://dx.doi.org/10.1016/j.jff.2017.12.031.

Elo, B., Villano, C. M., Govorko, D., \& White, L. A. (2007). Larval zebrafish as a model for glucose metabolism: expression of phosphoenolpyruvate carboxykinase as a marker for exposure to anti-diabetic compounds. Journal of Molecular Endocrinology, 38(4), 433-440. http://dx.doi.org/10.1677/JME-06-0037. PMid:17446233.

Gleeson, M., Connaughton, V., \& Arneson, L. S. (2007). Induction of hyperglycaemia in zebrafish (Danio rerio) leads to morphological changes in the retina. Acta Diabetologica, 44(3), 157-163. http:// dx.doi.org/10.1007/s00592-007-0257-3. PMid:17721755.

Gonçalves, A., Marques, C., Leal, E., Ribeiro, C. F., Reis, F., Ambrósio, A. F., \& Fernandes, R. (2014). Dipeptidyl peptidase-IV inhibition prevents blood-retinal barrier breakdown, inflammation and neuronal cell death in the retina of type 1 diabetic rats. Biochimica et Biophysica Acta. Molecular Cell Research, 1842(9), 1454-1463. http://dx.doi.org/10.1016/j.bbadis.2014.04.013. PMid:24769045.

Hatanaka, T., Inoue, Y., Arima, J., Kumagai, Y., Usuki, H., Kawakami, K., Kimura, M., \& Mukaihara, T. (2012). Production of dipeptidyl peptidase IV inhibitory peptides from defatted rice bran. Food Chemistry, 134(2), 797-802. http://dx.doi.org/10.1016/j.foodchem.2012.02.183. PMid:23107693.

Huang, S. L., Hung, C. C., Jao, C. L., Yung, Y. S., \& Hsu, K. C. (2014). Porcine skin gelatin hydrolysate as a dipeptidyl peptidase IV inhibitor improves glycemic control in streptozotocin-induced diabetic rats. Journal of Functional Foods, 11, 235-242. http://dx.doi.org/10.1016/j. jff.2014.09.010.
James, H. A., O’Neill, B. T., \& Nair, K. S. (2017). Insulin Regulation of Proteostasis and Clinical Implications. Cell Metabolism, 26(2), 310323. http://dx.doi.org/10.1016/j.cmet.2017.06.010. PMid:28712655.

Jannoo, Z., Wah, Y. B., Lazim, A. M., \& Hassali, M. A. (2017). Examining diabetes distress, medication adherence, diabetes self-care activities, diabetes-specific quality of life and health-related quality of life among type 2 diabetes mellitus patients. The Journal of Clinical Endocrinology, 9, 48-54. http://dx.doi.org/10.1016/j.jcte.2017.07.003. PMid:29067270.

Ji, W., Zhang, C. H., \& Ji, H. W. (2017). Purification, identification and molecular mechanism of two dipeptidyl peptidase IV (DPP-IV) inhibitory peptides from Antarctic krill (Euphausia superba) protein hydrolysate. Journal of Chromatography. B, Analytical Technologies in the Biomedical and Life Sciences, 1064, 56-61. http://dx.doi. org/10.1016/j.jchromb.2017.09.001. PMid:28915418.

Juillerat-Jeanneret, L. (2014). Dipeptidyl peptidase IV and its inhibitors: therapeutics for type 2 diabetes and what else? Journal of Medicinal Chemistry, 57(6), 2197-2212. http://dx.doi.org/10.1021/jm400658e. PMid:24099035.

Lacroix, I. M. E., \& Li-Chan, E. C. Y. (2012). Evaluation of the potential of dietary proteins as precursors of dipeptidyl peptidase (DPP)-IV inhibitors by an in silico approach. Journal of Functional Foods, 4(2), 403-422. http://dx.doi.org/10.1016/j.jff.2012.01.008.

Lacroix, I. M. E., \& Lichan, E. C. Y. (2016). Food-derived dipeptidylpeptidase IV inhibitors as a potential approach for glycemic regulation-Current knowledge and future research considerations. Trends in Food Science \& Technology, 54, 1-16. http://dx.doi. org/10.1016/j.tifs.2016.05.008.

Lawson, N. D., \& Weinstein, B. M. (2002). In vivo imaging of embryonic vascular development using transgenic zebrafish. Developmental Biology, 248(2), 307-318. http://dx.doi.org/10.1006/dbio.2002.0711. PMid:12167406.

Lee, B., Shi, L., Kassel, D. B., Asakawa, T., Takeuchi, K., \& Christopher, R. J. (2008). Pharmacokinetic, pharmacodynamic, and efficacy profiles of alogliptin, a novel inhibitor of dipeptidyl peptidase-4, in rats, dogs, and monkeys. European Journal of Pharmacology, 589(1-3), 306-314. http://dx.doi.org/10.1016/j.ejphar.2008.04.047. PMid:18538760.

Liang, X., Nie, X., Ying, G., An, T., \& Li, K. (2013). Assessment of toxic effects of triclosan on the swordtail fish (Xiphophorus helleri) by a multi-biomarker approach. Chemosphere, 90(3), 1281-1288. http:// dx.doi.org/10.1016/j.chemosphere.2012.09.087. PMid:23098581.

Liu, X., Harada, N., Yamane, S., Kitajima, L., Uchida, S., Hamasaki, A., Mukai, E., Toyoda, K., Yamada, C., Yamada, Y., Seino, Y., \& Inagaki, N. (2009). Effects of long-term dipeptidyl peptidase-IV inhibition on body composition and glucose tolerance in high fat diet-fed mice. Life Sciences, 84(25-26), 876-881. http://dx.doi.org/10.1016/j. lfs.2009.03.022. PMid:19358859.

Maher, B. (2009). Evolution: Biology's next top model? Nature, 458(7239), 695-698. http://dx.doi.org/10.1038/458695a. PMid:19360058.

Matheeussen, V., Lambeir, A. M., Jungraithmayr, W., Gomez, N., Mc Entee, K., Van der Veken, P., Scharpé, S., \& De Meester, I. (2012). Method comparison of dipeptidyl peptidase IV activity assays and their application in biological samples containing reversible inhibitors. Clinica Chimica Acta, 413(3-4), 456-462. http://dx.doi. org/10.1016/j.cca.2011.10.031. PMid:22093941.

Minkiewicz, P., Dziuba, J., \& Michalska, J. (2011). Bovine meat proteins as potential precursors of biologically active peptides-a computational study based on the BIOPEP database. Food Science \& Technology International, 17(1), 39-45. http://dx.doi. org/10.1177/1082013210368461. PMid:21364044. 
Montal, E., Dewi, R., Bhalla, K., Ou, L., Hwang, B., Ropell, A. E., Gordon, C., Liu, W. J., DeBerardinis, R. J., Sudderth, J., Twaddel, W., Boros, L. G., Shroyer, K. R., Duraisamy, S., Drapkin, R., Powers, R. S., Rohde, J. M., Boxer, M. B., \& Girnun, G. D. (2015). PEPCK Coordinates the Regulation of Central Carbon Metabolism to Promote Cancer Cell Growth. Molecular Cell, 60(4), 571-583. http://dx.doi.org/10.1016/j. molcel.2015.09.025. PMid:26481663.

Papasani, M. R., Gensure, R. C., Yan, Y. L., Gunes, Y., Postlethwait, J. H., Ponugoti, B., John, M. R., Juppner, H., \& Rubin, D. A. (2004). Identification and characterization of the zebrafish and fugu genes encoding tuberoinfundibular peptide 39. Endocrinology, 145(11), 5294-5304. http://dx.doi.org/10.1210/en.2004-0159. PMid:15297442.

Schmittgen, T. D., \& Livak, K. J. (2008). Analyzing real-time PCR data by the comparative CT method. Nature Protocols, 3(6), 1101-1108. http://dx.doi.org/10.1038/nprot.2008.73. PMid:18546601.

Stewart, A.M., Nguyen, M., Wong, K., Poudel, M.K. \& Kalueff, A.V. (2014). Developing zebrafish models of autism spectrum disorder (ASD). Progress in Neuropsychopharmacology \& Biological Psychiatry, 50, 27-36.

Sun, H. J., Zhang, J. Y., Wang, Q., Zhu, E., Chen, W. R., Lin, H. J., Chen, J. R., \& Hong, H. C. (2019). Environmentally relevant concentrations of arsenite induces developmental toxicity and oxidative responses in the early life stage of zebrafish. Environmental Pollution, 254(Pt A), 113022. http://dx.doi.org/10.1016/j.envpol.2019.113022. PMid:31408795.

Sun, J., \& Mao, X. (2016). An environmental friendly process for Antarctic krill (Euphausia superba) utilization using fermentation technology. Journal of Cleaner Production, 127, 618-623. http:// dx.doi.org/10.1016/j.jclepro.2016.04.020.

Thomas, R. L., Halim, S., Gurudas, S., Sivaprasad, S., \& Owens, D. R. (2019). IDF Diabetes Atlas: A review of studies utilising retinal photography on the global prevalence of diabetes related retinopathy between 2015 and 2018. Diabetes Research and Clinical Practice, 157, 107840. http://dx.doi.org/10.1016/j.diabres.2019.107840. PMid:31733978.
Tiso, N., Moro, E., \& Argenton, F. (2009). Zebrafish pancreas development. Molecular and Cellular Endocrinology, 312(1-2), 24-30. http://dx.doi. org/10.1016/j.mce.2009.04.018. PMid:19477220.

Tulipano, G., Sibilia, V., Caroli, A. M., \& Cocchi, D. (2011). Whey proteins as source of dipeptidyl dipeptidase IV (dipeptidyl peptidase-4) inhibitors. Peptides, 32(4), 835-838. http://dx.doi.org/10.1016/j. peptides.2011.01.002. PMid:21256171.

Wang, L., Xue, C., Xue, Y., Wang, Y., \& Li, Z. (2015). Optimization and evaluation of a novel technique for hydrolyzing Antarctic krill (Euphausia superba) proteins. Food and Bioproducts Processing, 94, 629-636. http://dx.doi.org/10.1016/j.fbp.2014.08.010.

Wang, Z., Mao, Y., Cui, T., Tang, D., \& Wang, X. L. (2013). Impact of a combined high cholesterol diet and high glucose environment on vasculature. PLoS One, 8(12), 81-85. http://dx.doi.org/10.1371/ journal.pone.0081485. PMid:24349075.

Yabe, D., Kuroe, A., Watanabe, K., Iwasaki, M., Hamasaki, A., Hamamoto, Y., Harada, N., Yamane, S., Lee, S., Murotani, K., Deacon, C. F., Holst, J. J., Hirano, T., Inagaki, N., Kurose, T., \& Seino, Y. (2015). Early phase glucagon and insulin secretory abnormalities, but not incretin secretion, are similarly responsible for hyperglycemia after ingestion of nutrients. Journal of Diabetes and Its Complications, 2(3), 413-421. http://dx.doi.org/10.1016/j.jdiacomp.2014.12.010. PMid:25613093.

Yamamoto, T., Shimano, M., Inden, Y., Takefuji, M., Yanagisawa, S., Yoshida, N., Tsuji, Y., Hirai, M., \& Murohara, T. (2015). Alogliptin, a dipeptidyl peptidase-4 inhibitor, regulates the atrial arrahythmogenic substrate in rabbits. Heart Rhythm, 12(6), 1362-1369. http://dx.doi. org/10.1016/j.hrthm.2015.03.010. PMid:25757661.

Zhang, Y., Chen, Y., Cheng, J., Guo, Z., Lu, Y., \& Tian, B. (2015). DPP IV inhibitor suppresses STZ-induced islets injury dependent on activation of the IGFR/Akt/mTOR signaling pathways by GLP-1 in monkeys. Biochemical and Biophysical Research Communications, 456(1), 139-144. http://dx.doi.org/10.1016/j.bbrc.2014.11.048. PMid:25446112. 